\title{
The INFluence OF THINK-PAIR-SHARE In ENHANCING STUdents' SPEAKING ABILITY
}

\author{
Hidayana Putri ${ }^{1)}$, Fahriany $^{2)}$, Nasifuddin Jalil ${ }^{3)}$ \\ ${ }^{1)}$ UIN Syarif Hidayatullah Jakarta, Indonesia \\ E-mail: putrihidayana@gmail.com \\ 2) UIN Syarif Hidayatullah Jakarta, Indonesia \\ E-mail: fahriany@uinjkt.ac.id \\ 3) UIN Syarif Hidayatullah Jakarta, Indonesia \\ E-mail:nasifuddinjalil@uinjkt.ac.id
}

\begin{abstract}
Secondary schools obliged the students to master English skills. In fact, students have many shortcomings in mastering those English skills, especially speaking skills faced by the eighth-grade students of MTs Khazanah Kebajikan in the academic year 2017/2018. They had difficulties in speaking English directly. It was found by our observation in which the students were lack of vocabulary, self-confidence, and motivation. Additionally, they were difficult to elaborate on their ideas through the spoken form. Hence, the students are needed the new strategy to construct their shortcomings by the implementation of Think-Pair-Share. The objective of the study was to know the influence of Think-Pair-Share on students' speaking ability of short monologue. This study used a quantitative method with a quasiexperimental design. The population was 102 students with 50 students as the sample of this study. The technique of data collection in this study consisted of pre-test and post-test. The data analysis techniques were used t-test, also included the test of normality and homogeneity. In addition, this study was also supported by measuring the effect size. The result of the study showed that students' speaking score in the experimental class was higher than the controlled class. It found that $\mathrm{H}_{0}$ (Null Hypothesis) is rejected and $\mathrm{H}_{\mathrm{a}}$ (Alternative Hypothesis) is accepted. Also, the result of the effect size was 2.91 at a large level (significant). It can be concluded that Think-Pair-Share is an effective way to improve students' speaking ability, especially in short monologue.
\end{abstract}

Keywords: Think-Pair-Share; Speaking; Short Monolog; Quasi-Experimental

\section{INTRODUCTION}

Speaking is an essential part of language learning. Students who can speak means they can share their ideas and opinions with listeners through speaking. The crucial thing in speaking is how to convey ideas as well and make the listener understand what the speaker is saying. Students also improve their abilities and confidence if they can communicate with others in English, mainly native speakers. It shows that speaking is a process of sharing ideas and thoughts to communicate with others verbally. People need to communicate with other people they must master these skills to be able to convey information and thoughts through speaking. Speaking is a part of everyday life that is taken for granted, where thousands of people produce tens of thousands of words (Carnegie, 2017). As humans, people learn to speak at least one language (the language people hear) when they grow up. Thus, in speaking people can form new opinions or ideas about something to tell people properly. In addition, talking is an activity that involves someone to exchange ideas through talking. Kuśnierek (2015) stated that speaking is part of an activity in which a person interacts with others. Through speaking, students can express ideas and feelings spontaneously. Therefore, they can share information, advice and comments with others through communication.

To achieve students' speaking ability, they must conduct short monologues in class to improve their speaking abilities. In other words, speaking is one of the valuable skills that make students have the achievement to speak or present something in front of others. A short monologue is a type of spoken language used by a speaker in class to 
convey a message or idea about something (Derakhshan, Khalili, \& Beheshti, 2016). By sending a message or idea, listeners are expected to receive it too. However, if the speaker cannot deliver it well, the listener will not be able to receive it well either. By doing a short monologue, students can encourage their speaking skills better. Short monologues are speeches or verbal presentations delivered by someone (Astuti, 2018). It means that students are allowed to talk throughout the class by presenting an object.

In secondary school, the purpose of speaking from the eighth grade is to make students able to express meaning in transactional (to get things done) and interpersonal conversations (to socialize) based on everyday contexts. In addition, students are intended to express the meaning of short functional oral texts and formally descriptive monologues based on their daily lives. This objective relates to syllabus indicators in the 2013 curriculum where students can express descriptive information text types, students can identify the short informative texts they hear, students can identify the characteristics of the linguistic texts they hear, and students can do a short monologue from descriptive texts. In conducting pre-research at school, we conducted a short oral monologue test about describing images to determine students' speaking abilities. By doing a short monologue, students quickly increase their confidence well. It is very important because based on junior high school syllabus indicators in the 2013 curriculum, students must be mastered in communicative activities with others functionally about people, animals, and things around them. However, some students have difficulty speaking English. Difficulties are also faced by students of MTs Khazanah Kebajikan. Some of the difficulties students face, such as students' lack of vocabulary, lack of grammar knowledge, students' lack of confidence because they are afraid of making mistakes, students lack motivation so they cannot express their opinions well, and their speaking achievement has not improved success. Shortly, students cannot speak English fluently when they speak or present something in class.

Think-Pair-Share is a type of cooperative learning that aims to organize classroom activities on academic and social learning experiences (Nasution \& Surya, 2017). Based on the problems we have observed, we want to research the influence of Think-Pair-Share on students' speaking abilities from short monologues because it is an effective way and appropriate strategy to help students improve their speaking skills. Students must work in groups to complete assignments collectively towards academic goals. Besides, cooperative learning is a method of learning where students communicate in small groups and work with others cooperatively (Gupta \& Pasrija, 2016). The benefits of cooperative learning help students to encourage positive attitudes in learning, to get along with others, and to develop cooperation to help each other (Johnson \& Johnson, 2017; Lee et al., 2016; Farrell \& Jacobs, 2016). Additionally, Think-Pair-Share is an effective strategy because students become active learners who communicate directly with their friends, speak English without hesitation and feel free to share information or new knowledge (Fatkur \& Retnaningsih, 2017). That is to say, this strategy will build students' motivation in speaking English because they feel enthusiastic when the teacher gives positive feedback to students about their achievements in speaking ability.

Further, several researchers had researched think-pairshare in quantitative methods. Ardhy (2018) conducted his research on the application of Think-Pair-Share to improve students' speaking skills in the fourth-semester students of Cokroaminoto University Palopo. This study uses a quasiexperimental design through pre-test and post-test. The results showed that the application of Think-Pair-Share strategies could significantly improve students' speaking abilities. Then, Alrayah (2018) conducted a study to test the effectiveness of cooperative learning activities in improving the fluency of EFL students. First-year students studying English at the Faculty of Education at Omdurman Islamic University, Sudan are a research sample. This study uses experimental and control groups. The results showed a statistically significant correlation between Cooperative Learning activities and increased speaking fluency of EFL students. In addition, Utami and Yuneva (2018) researched the effect of Think-Pair-Share (TPS) strategies and reading motivation on students' reading comprehension. This study uses an experimental study whose research population is the second-semester students of the Faculty of Law, Prof. University Dr. Hazairin, SH Bengkulu. The results showed that the Think-Pair-Share (TPS) strategy had a significant effect on students' reading comprehension. That is to say, we are interested to know that Think-Pair-Share can improve students' speaking ability about short monologues. Besides, we use a short descriptive monologue as our research at the eighth-grade students of MTs Khazanah Kebajikan in the academic year 2017/2018.

\section{Methodology}

This research used quantitative methods to collect and evaluate data. The quantitative method is about investigating phenomena by collecting numerical data that is analyzed using mathematical methods, especially statistics (Tracy, 2019). Therefore, this research was conducted to determine the influence of Think-Pair-Share on students' speaking ability of short monologue at the eighth-grade students of MTs Khazanah Kebajikan through pre-test and post-test to obtain scores and statistical data. Then, this research uses a quasi-experimental design. It involved two groups; they were the experimental group and the control group. Besides, the experimental group means students who are treated using Think-Pair-Share. Meanwhile, a controlled group means students who are not treated using Think-Pair-Share. This research was conducted for six meetings twice a week for eighty minutes, including giving pre-test, treatment, and post-test. Additionally, the population of this research was the eighthgrade students of MTs Khazanah Kebajikan consisted of four classes. The total number of population was 102 students. This research uses purposive sampling to select samples. Purposive sampling is a technique for selecting 
samples to rely on research assessments when selecting population members to participate in research (Black, 2010: 225).

The research instrument used in this research was a test. Tests are given in the form of pre-test and post-test. Then, data collection techniques in this research consisted of pretest and post-test. Pre-test and post-test are given to students of the experimental class and the control class. The pre-test is given at the beginning of the meeting before treatment. Meanwhile, the post-test was given at the last meeting after treatment four times. Thus, the pre-test and post-test scores in the experimental class were compared with the control class. After that, scores are used as numerical data to measure students' short monologue speaking abilities after Think-Pair-Share is applied. Besides, we conducted a validity and reliability test to know the test is valid or not and how reliable the instrument for the data collection (Kane, 2016; Dikko, 2016).

Besides, data in this research were analyzed using statistical analysis. We compared the pre-test and post-test scores in the experimental class and the control class. In analyzing data, the t-test was used to determine the influence of Think-Pair-Share on students' speaking abilities from short monologues. Before analyzing t-tests, tests of normality, homogeneity, and the effect size must be measured first. It is used to determine whether the two variables $\mathrm{X}$ (independent variable) and $\mathrm{Y}$ (dependent variable) are normally distributed. Scores in the normality test must be higher than 0.05 to get normal data. Besides, homogeneity testing was performed to determine the similarity of the $\mathrm{Y}$ variable score, which has been categorized with the variable $\mathrm{X}$ score. The test score must be higher than 0.05 to get homogeneous data. Then, the effect size of applying media or techniques can be convinced using the effect size formula, whether it is small, medium, or large.

\section{RESULTS AND DISCUSSION}

The data described here are the results of the speaking test. As mentioned earlier, this research uses a quasiexperimental design. This research is mainly intended to find out whether students' speaking ability about short monologues can be improved through Think-Pair-Share. In this research, there are two data collection techniques, namely pre-test and post-test. In the pre-test, students are instructed to make a brief description of "Explaining Your Favorite Food" individually then they do it in front of the class. In the post-test, students are instructed to make a brief description of "Describing Your Idol." We conducted a pretest at the first meeting, then we applied treatment four times, and at the last meeting, we conducted a post-test after undergoing treatment. After presenting teaching material in an experimental and controlled class, students' speaking abilities about short monologues can be measured. The test instrument is a test where students are asked to do a short monologue oral test.

Moreover, the mean score of the pre-test in the experimental class was 53.92, while the mean score of the pre-test in the control class was 55.52. It can be seen that the scores of the two classes indicate that there is a difference between student achievement in pre-test scores (the experimental class and the control class), the control class gets an average score that is higher than the experimental class. It means that the ability to talk about short monologues in the experimental class needs to be improved further. Meanwhile, the experimental class got the lowest score than in the control class. In the experimental class, there is one student who scores in the range 31-40, four students who score in the range 41-50, nineteen students who score in the range 51-60, and one student who scores in the range 31-40 and range 61-70. While, in the controlled class, two students scored in the range 31-40, four students who scored in the range of 41-50, seventeen students who scored in the range of 51-60, and two students who scored in the range 31-40 and range 61-70. Then, it can be seen in Fig. 1 that the controlled class gets the highest score in the pre-test than the experimental class.

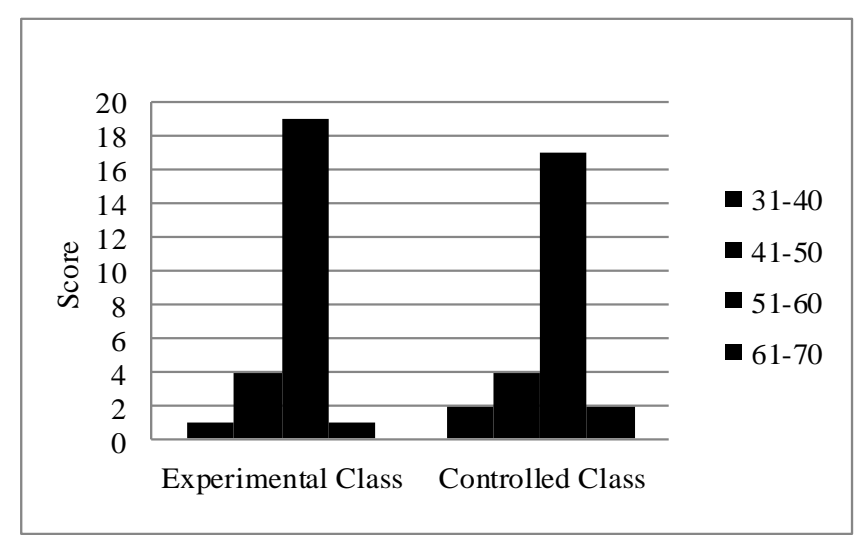

Fig. 1 The Students' Pre-Test Scores of Experimental Class and Controlled Class

Nevertheless, after the treatment is applied, the post-test score in the experimental class and the control class informs that the average post-test score in the experimental class is 79.28 , and the average post-test score in the control class is 66.56. This means that there are significant post-test scores in the experimental class and the control class, the score of the control class increases in the post-test rather than in the pre-test. However, in the post-test, the experimental class scored higher than the control class. That proves that there is a Think-Pair-Share gives a positive impact on students' short monologue speaking abilities. Besides, there have been many improvements in student achievement in speaking skills. It can be seen in the experimental class, seventeen students scored in the range of 71-80, and eight students who scored in the range of 81-90. Also, in the experimental class, there were no students who scored in the range 51-60 and 61-70. Meanwhile, in the controlled class, seven students scored in the range of 51-60, twelve students who scored in the range of 61-70, and six students who scored in the range of 71-80. Then, that means that in the post-test, the experimental class got the highest score than 
the controlled class, which had a Think-Pair-Share effect on students' speaking ability from a short monologue.

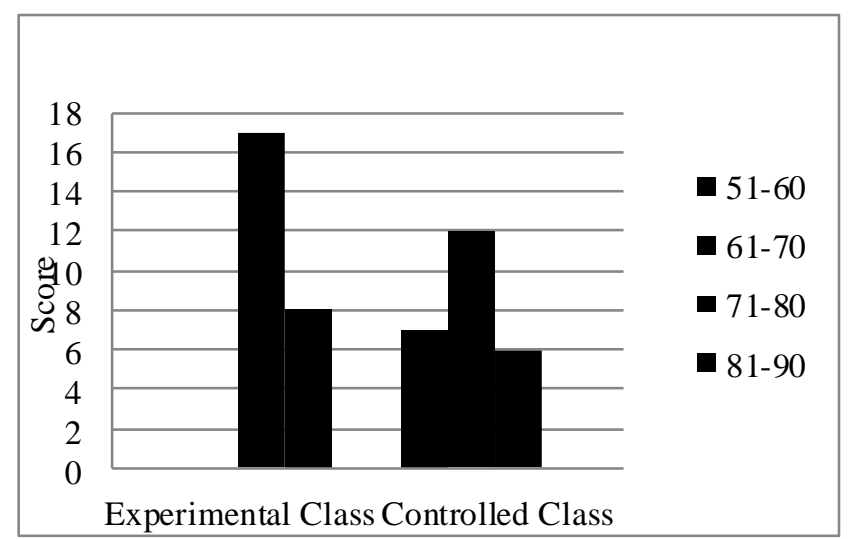

Fig. 2 The Students' Post-Test Scores of Experimental Class and Controlled Class

Furthermore, the normality test is found that the absolute difference (D) from the experimental class data was 0.147 . It is smaller than the absolute difference in the KolmogorovSmirnov table with the closest Kolmogorov-Smirnov critical point of $25=0.264$. It means that the experimental class data pre-test is normal. Furthermore, Kolmogorov-Smirnov $\mathrm{Z}$ data in the experimental class was 0.736 , and the control class was 1.444 . It is higher than the probability score of 0.05 . So, it can be concluded that the pre-test data in the experimental class and the control class are normally distributed. Then, normality in the post-test found that the absolute difference (D) from the experimental class data was 0.149 . This is smaller than the absolute difference in the Kolmogorov-Smirnov table with the closest KolmogorovSmirnov critical point of $25=0.264$. It means that the experimental class data post-test is normal. Besides, the absolute difference (D) from the controlled class data is 0.222. It is much lower than the Kolmogorov-Smirnov critical points. It means the controlled class data post-test is normal. Furthermore, Kolmogorov-Smirnov $\mathrm{Z}$ data in the experimental class was 0.747 , and the controlled class was 1.111. This is higher than the probability score of 0.05 . Then, it can be concluded that the post-test data in the experimental class and the control class are normally distributed.

Next, the homogeneity test is to find out whether the data is homogeneous or not. If the result of data calculation is higher than 0.05, the data is homogeneous. Homogeneity of the pre-test found that the experimental class and the control class were 0.050 . This means that the variance homogeneity data is homogeneous because the pre-test score is higher than the probability score, which is $0.05(0.050>0.05)$. Meanwhile, in the post-test, the results of the experimental class and the control class were 0.377 . This means that the variance homogeneity data is homogeneous because the post-test score is more than the probability score of 0.05 $(0.377>0.05)$. Then, the post-test $t$-test showed that $\mathrm{t}(48)=$ $10,071, \mathrm{p}=0,000$ meant that there was a significant difference between the experimental class (Mean $=79.28$,
Standard Deviation $=3.446$ ) and the controlled class (Mean $=66,56$, Standard Deviation = 5,292). Then, the "Independent Samples Test" illustrates the statistical hypothesis of this study. It can be seen that the $t$ value result is 10,071 , followed by Sig. (2-tailed) 0,000. Then, it can be stated that $\mathrm{t}$ value $(10,071)>\mathrm{t}$ table $(1,677)$ and Sig. (2tailed) is $0,000<0.05$. It shows that Think-Pair-Share can improve students' speaking ability about short monologues. Besides, according to the effect size criteria, it can be assured that the results of the calculation of the effect size of this research are large. It can be seen from the $\mathrm{d}$ score of 2.91. It means that the influence of Think-Pair-Share on students' speaking ability about short monologues is significant.

Based on data calculations and the process of conducting research, there is some information that is explained as follows. In the pre-test, the experimental class and the control class did the test well. There were 25 students in the experimental class whose pre-test mean score was 53.92 before applying Think-Pair-Share. According to Arends (2012), there are three steps in doing Think-Pair-Share such as, thinking alone about answers, pairing up to discuss what they have thought, and sharing what they talk about with the whole class. Furthermore, through Think-Pair-Share, students' speaking ability about short monologues in eighth grade MTs Khazanah Kebajikan increased. After giving treatment in applying Think-Pair-Share four times, the average post-test score of students was 79.28, and the highest score obtained was 38 . The minimum score on the pre-test was 40 , and the maximum score was 62 . The minimum score for the post-test was 73 , and the maximum score was 86 . In short, the minimum and maximum scores on the post-test were higher than the pre-test in the experimental class.

Besides, based on data analysis, it interpreted the results of the pre-test normality test in the experimental class as a normal distribution. Then, based on t-test calculations, the results of the post-test in the experimental class and the control class showed $t(48)=10,071, p=0,000$. It means that there is a significant difference between the experimental class $($ Mean $=79.28$, Standard Deviation $=$ 3.446 ) and the controlled class (Mean $=66.56$, Standard Deviation $=5.292)$. Thus, the results of $t$ value and table show that $\mathrm{t}$ value $(10,071)>\mathrm{t}$ table $(1,677)$ and Sig. (2tailed) is $0,000<0.05$ where $\mathrm{H}_{0}$ (Null Hypothesis) is rejected, and $\mathrm{Ha}$ (Alternative Hypothesis) is accepted. It means that the average score of the experimental class is higher than the average score of the controlled class. So, it can be concluded that there is a Think-Pair-Share effect on students' speaking ability on short monologues. Furthermore, there is a significant difference between students' scores in short monologue speaking abilities using Think-Pair-Share and students' scores in short monologue speaking skills without using Think-Pair-Share in eighth grade MTs Khazanah Kebajikan. It is evidenced by the effect size of 2.91, which means that the level of effect size criteria is large. It means that there is a Think-Pair-Share effect on students' short monologue speaking abilities. It is 
also supported by research in previous studies that cooperative learning methods such as Think-Pair-Share are very helpful and effective in teaching short speaking monologues because students practice in English with confidence and they are not afraid to make mistakes (Cahyani, 2018; Hasibuan, 2018; Nievecela \& OrtegaAuquilla, 2019).

To sum up, the application of Think-Pair-Share has a positive effect on students' speaking ability about short monologues. Students can speak fluently and confidently after they have been taught using Think-Pair-Share. As a result, the steps in Think-Pair-Share facilitate them to have the opportunity to practice and to encourage their motivation in speaking English (Abidin, Amin, \& Sulaiman, 2018). Besides, Think-Pair-Share requires them to be active speakers in every activity and teaching speaking using Think-Pair-Share is very fun and beneficial, especially for eighth-grade students of MTs Khazanah Kebajikan in academic year 2017/2018.

\section{CONCLUSIONS}

Based on the findings and discussion, it shows that the short monologue students' speaking ability in eighth grade MTs Khazanah Kebajikan in the academic year 2017/2018 can be improved through Think-Pair-Share. That can be seen with the average value of students increasing. After conducting the treatment followed by a post-test, student achievement in monologue speaking ability increased. It can be found that $\mathrm{H}_{0}$ (Null Hypothesis) is rejected and $\mathrm{H}_{\mathrm{a}}$ (Alternative Hypothesis) is accepted. Also, the result of the effect size was 2.91 at a large level (significant). It can be said that there is a Think-Pair-Share effect on students' speaking abilities on short monologues. Besides, the weakness of this research is still limited with the time in implementing the actions. Other researchers who are interested in the same field are recommended to implement the actions in a longer period to get more maximum results so that the improvement will be more significantly seen.

\section{REFERENCES}

Abidin, C., Amin, S. M., \& Sulaiman, R. (2018). The Effect of Think-Pair-Share Learning with Contextual Approach on Junior High School Students' Mathematics Problem Solving Ability. In Mathematics, Informatics, Science, and Education International Conference (MISEIC 2018). Atlantis Press.

Alrayah, H. (2018). The Effectiveness of Cooperative Learning Activities in Enhancing EFL Learners' Fluency. English Language Teaching, 11(4), 21-31.

Ardhy, S. (2018). The Application of Think-Pair-Share Strategy in Improving Students' Speaking Ability. IDEAS: Journal on English Language Teaching and Learning, Linguistics and Literature, 6(2).

Arends, R. I. (2012). Learning to Teach. Ninth Edition. McGraw-Hill.
Astuti, R. P. (2018). The Effect of Student Presentation on the Eleventh Grade Student's Speaking Skill at SMA Negeri 24 Kabupaten Tangerang. Globish: An English-Indonesian Journal for English, Education, and Culture, 7(2).

Black, K. (2010). Business Statistics: Contemporary Decision Making, Sixth Edition. John Willey \& Sons Ltd.

Cahyani, F. (2018). The use of Think Pair Share technique to improve students' speaking performance. Research in English and Education Journal, 3(1), 76-90.

Carnegie, D. (2017). How to develop self-confidence and influence people by public speaking. Simon and Schuster.

Derakhshan, A., Khalili, A. N., \& Beheshti, F. (2016). Developing EFL learner's speaking ability, accuracy and fluency. English Language and Literature Studies, 6(2), 177-186.

Dikko, M. (2016). Establishing construct validity and reliability: Pilot testing of a qualitative interview for research in Takaful (Islamic insurance). The Qualitative Report, 21(3), 521-528.

Farrell, T. S., \& Jacobs, G. M. (2016). Practicing What We Preach: Teacher Reflection Groups on Cooperative Learning. Tesl-Ej, 19(4).

Fatkur, R., \& Retnaningsih, H. W. (2017). The Effectiveness of Think-Pair-Share Technique (TPS) to Teach Reading Comprehension (An Experimental Study at The Eight Grade Students of SMP N 1 Juwiring in 2013/2014 Academic Year). Doctoral dissertation. IAIN Surakarta. Unpublished.

Gupta, M., \& Pasrija, P. (2016). Co-Operative Learning: an Efficient Technique To Convert Students Into Active Learners in Classrooms. MIER Journal of Educational Studies, Trends and Practices, 2(1).

Hasibuan, L. M. S. (2018). The Effect of Think-Pair-Share to the Students' Speaking Ability of Short Monolog. Jurnal ESTUPRO, 3(3), 22-30.

Johnson, D. W., \& Johnson, R. T. (2017). The use of cooperative procedures in teacher education and professional development. Journal of education for teaching, 43(3), 284-295.

Kane, M. T. (2016). Explicating validity. Assessment in Education: Principles, Policy \& Practice, 23(2), 198-211.

Kuśnierek, A. (2015). Developing students' speaking skills through role-play. World Scientific News, 7, 73-111.

Lee, H., Parsons, D., Kwon, G., Kim, J., Petrova, K., Jeong, E., \& Ryu, H. (2016). Cooperation begins: Encouraging critical thinking skills through cooperative reciprocity using a mobile learning game. Computers \& Education, 97, 97-115.

Nasution, Y. S., \& Surya, E. (2017). Application of TPS Type Cooperative Learning in Improving Student's Mathematics Learning Outcomes. International 
Journal of Sciences Basic and Applied Research (IJSBAR), 34(1), 116-125.

Nievecela, L. C., \& Ortega-Auquilla, D. (2019). Using Cooperative Learning Strategies to Develop Rural Primary Students' English Oral Performance. English Language Teaching, 12(11), 74-84.

Tracy, S. J. (2019). Qualitative research methods: Collecting evidence, crafting analysis, communicating impact. John Wiley \& Sons.

Utami, E., \& Yuneva, Y. (2018). The Effect of Think Pair Share Strategy and Students' Reading Motivation toward Students' Reading Comprehension at Second Semester Students of Law Faculty Universitas Prof. Dr. Hazairin, SH Bengkulu. English Language Teaching and Research, 2(1). 